of a new Griffithides from the Permian Nosoni form. ation, its nearest known relative being $G$. acanthiceps from the Carboniferous limestone of England. A second paper by the same author discusses and redescribes the original type specimen of Vogdes' Phillipsia (Griffithides) ornatus from the Lower Coal measures, Conway County, Arkansas, renaming it Griffithides conwayensis.

\section{Bird Sanctuaries in London}

THE industry of the voluntary observers who report to the Committee on Bird Sanctuaries in the Royal Parks (England) gives a wonderfully full picture of bird-life in Greater London (Report of Committee for 1934. London: H.M. Stationery Office. 6d. net.). In Richmond Park, 56 species bred, and 38 other species were seen or heard; in Bushey and Hampton Court Parks, 52 species nested, including kingfisher and nightingale, and 26 others were seen. But the surprising thing is that, in the midst of the commotion of London itself-in Hyde Park and Kensington Gardens - there should appear visitors like the red-throated diver, the Slavonian grebe, and the golden-eye duck, all of them recorded for the first time in that area. It is said also that the Scandinavian form of the lesser black-backed gull appeared on the Serpentine in the autumn of 1933. Curious diversity in choice of roosting sites is shown by starlings and wood-pigeons : every evening about sunset, during autumn and winter, the latter leave St. James's Park, where there are plenty of suitable roosts, to spend the night in Battersea Park ; and they make use of the very trees which some of the 2,000 starlings have sampled and abandoned before they continue their journey to roost in St. James's Park, which the pigeons have just left.

\section{Research in the Tortugas Laboratory}

THE section in the Year Book, No. 33 (1934) of the Carnegie Institution of Washington dealing with this station reports a number of workers during the season and a great variety of subjects. Although much work is done in the field, there is a notable increase from year to year in the use of apparatus requiring electric current. This will pobably necessitate the installation of a power plant of greater capacity in the future. Dr. Alan Boyden, continuing his serological studies of invertebrates, has used examples from many different phyla, including 7 molluses, 4 arthropods, 8 echinoderms and 5 chordates. The results have been very satisfactory, and will enable light to be shed upon some of the more obscure relationships between the major groups of animals. Other researches include a study of the ecology and physiology of corals by Prof. C. M. Yonge, who found that the opportunity to examine the reefs in detail was of special value in view of his previous experience with Pacific coral reefs, and Mr. J. E. Harris's observations on the swimming movements of fishes, which embrace work on the fishes in their natural surroundings besides cinematographic experiments with special relation to their fins, whilst Prof. W. H. Longley's subject is the systematics of the Tortugas fishes.

\section{Marine Research at Cullercoats}

THE Report for the year ending July 31, 1934, of the Dove Marine Laboratory, Cullercoats, Northumberland (Armstrong College), published by the Marine Laboratory Committee and drawn up by the director, Prof. A. D. Hobson, shows it was a period of expansion of the activities of the Laboratory. The research work of the staff has been well maintained and there has been an increase in the number of outside workers. A number of alterations have been made in the building, including the conversion of a little-used lecture room into a new laboratory in which about a dozen students can be accommodated, or five research workers. This can be used for experimental and chemical work for which the main laboratory is not suitable. The work on herring has been continued as agreed with the Ministry of Agriculture and Fisheries, samples from the catches from the local shoals landed at North Shields during the season of 1933 being duly examined. Further investigations on the shoals from other parts of the coast have been continued. In Dr. Bull's work on conditioned responses in fishes, special attention is being paid to temperature, and it is found that teleostean fishes generally are extremely sensitive to temperature and that they can react to it purposively. Experiments on the perception of changes in salinity are now progressing satisfactorily. An excellent paper on the British Sphæromatidæ (Crustacea Isopoda) by Joseph Omer-Cooper and J. Hedley Rawson is included in this report. One of the species (Limnoria lignorum) is of economic importance as it is a wood-boring form and very widely distributed. A detailed discussion on the distribution of the Sphæromatidæ is included. In his aquarium observations Dr. Bull makes some important observations on the enemies of the common star-fish Asterias rubens, and shows that it is the only food eaten readily by the sun-stars Solaster papposus and $S$. endica and the northern stone-crab Lithodes maia. Adult specimens of all three can be maintained in captivity for long periods on such a diet.

\section{British Association Mathematical Tables}

Progress in the publication of these tables has been rather slower than was anticipated, chiefly owing to the great labour required in correcting the proofs. Vol. 5, containing the prime factors of all numbers up to 100,000 , has now been passed for printing. Tables for cyclotomy and trinomial congruences, offered by Prof. L. E. Dickson, have been accepted for publication. With regard to Bessel functions, at least three volumes will be required. The first of these (forming vol. 6 of the Tables) is now in the press, and will be published shortly. The calculations for the other volumes will absorb the greater part of the Committee's time and money during the next year.

\section{German Chemical Industry}

SHORT summaries of papers delivered at the conference of the Deutsche Gesellschaft für Chemisches

(Continued on page 601.) 